\begin{tabular}{|c|c|c|}
\hline UFG & \begin{tabular}{|c|} 
GEOAMBIENTE ON-LINE \\
Revista Eletrônica do Curso de Geografia - Campus Jatai- UFG \\
Graduação e Poss-Graduação em Geografia \\
www2.jataia.ufg.br/ojs/index.php/geoambiente \\
Apoio: PRPPG/PROAPUPEC \\
| Jataí-GO | n.13 | jul-dez/2009 |
\end{tabular} & $\begin{array}{l}\text { L̊ GEO } \\
\text { L̇AMBIENTE } \\
\text { ISSN } 1679-9860\end{array}$ \\
\hline
\end{tabular}

\title{
UM PASSEIO PELA CIDADE: NOTAS GEOGRÁFICAS SOBRE A VIDA SOCIAL NA METRÓPOLE ${ }^{1}$
}

\section{Diogo da Silva Cardoso ${ }^{2}$}

(2 - Universidade do Estado do Rio de Janeiro, Mestrando em Geografia - UERJ. Rua, São Francisco Xavier, ${ }^{\circ}$ 524, Pavilhão João Lyra Filho, $4^{\circ}$ andar, Bloco F, sala 4006, bairro Maracanã. CEP: 20550-013 - Rio de Janeiro, RJ. Telefone: (21) 2587-7287. E-mail: diogo_georeg@yahoo.com.br)

\section{Resumo}

A metrópole é uma forma simbólica, impregnada de memória, conflitos, projetos e interações socioespaciais. Neste artigo, que de maneira alguma pretende esgotar o tema, o objetivo é investigar a metrópole na sua complexidade e polivocalidade, onde, longe de ser uma totalidade harmoniosa, vem apresentando graves problemas e conflitos de ordem sociopolítico-espacial, e as metrópoles brasileiras não escapam dessa constatação. Ao longo do texto, questões como segregação espacial, criminalidade, (in)governabilidade urbana e reprodução ampliada do capital serão abordados, buscando as formas como essas problemáticas se territorializam na cidade e refletem as desigualdades instituídas pela ordem vigente. Não obstante, ressaltaremos também os projetos e práticas alternativas elaboradas no interior e nas bordas dos espaços/redes de poder e decisão. São novas geografias de uso e ressignificação do espaço urbano que conferem dinamismo, solidariedade e diversidade à vida cotidiana, impelindo a Geografia a um novo olhar (que não seja de "sobrevôo") sobre as grandes cidades, notadamente no contexto brasileiro.

Palavras-chave: metrópole, sociedade, território.

\footnotetext{
Abstract

${ }^{1}$ Este artigo consiste num capítulo da monografia "Escritos geográficos sobre a cidade contemporânea", a ser apresentada na UFF para obtenção do bacharelado em Geografia.

Artigo recebido para publicação em 30 de Junho de 2009;

Artigo aprovado para publicação em 05 de Outubro de 2009 


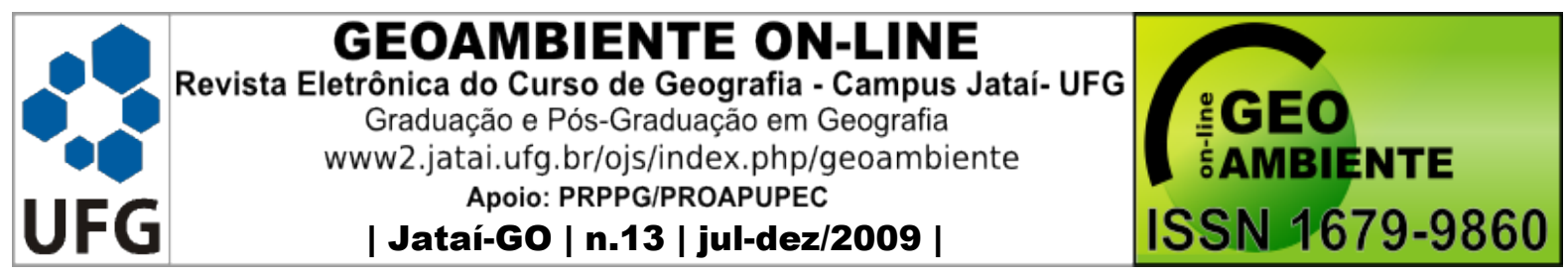

A WALK IN THE CITY: GEOGRAPHIC NOTES ABOUT SOCIAL LIFE IN A METROPOLIS

The metropolis is a symbolic form, full of memories, conflicts, projects, and socio-spatial interactions. In this article, which does not intent to end up the theme, the goal is to investigate the metropolis in its complexity and different vocallities, where, far from being a harmonious totality, it has been showing serious sociopolitical and spatial problems and conflicts, including the Brazilian metropolises. Throughout the article, questions like spatial segregation, criminality, urban administration and enlarged reproduction of capital are approached, looking for how these problems appear in the city and how they reflect the inequality established by the current order. Nevertheless, we will emphasize the projects and alternative practices developed in and outside of spaces/nets of power and decision. New geographies for the usage and attribution of new meanings for the urban space grant dynamism, solidarity, and diversity to the daily life, impelling a new vision to Geography (but not an "overflying") about big cities, especially in the Brazilian context.

Key-words: metropolis, society, territory.

\section{1 - Introdução}

Para início de reflexão, é fácil afirmar que as ciências humanas, ao longo do processo de institucionalização pela qual passaram no ocidente ${ }^{3}$, depararam-se insistentemente com princípios filosóficos e questionamentos empíricos que levaram, quase sempre, a apontamentos e conclusões baseados em dicotomias. Em outros termos, o antagonismo entre pares opostos, imersos numa relação causal, é que define a realidade das "coisas".

Até hoje reproduzimos dualidades, mesmo aquelas aparentemente "neutras", de pouca influência na formação do pensamento e das práticas cotidianas.

A Geografia possui um vasto temário na qual as dicotomias reinam como absolutas, sem as quais a ciência não vingaria. Cidade x campo, sociedade x natureza, rural x urbano, materialismo $\mathrm{x}$ idealismo..., aparência $\mathrm{x}$ essência..., forças produtivas $\mathrm{x}$ relações de

\footnotetext{
${ }^{3}$ Para esse assunto, ver Foucault (2007).
} 


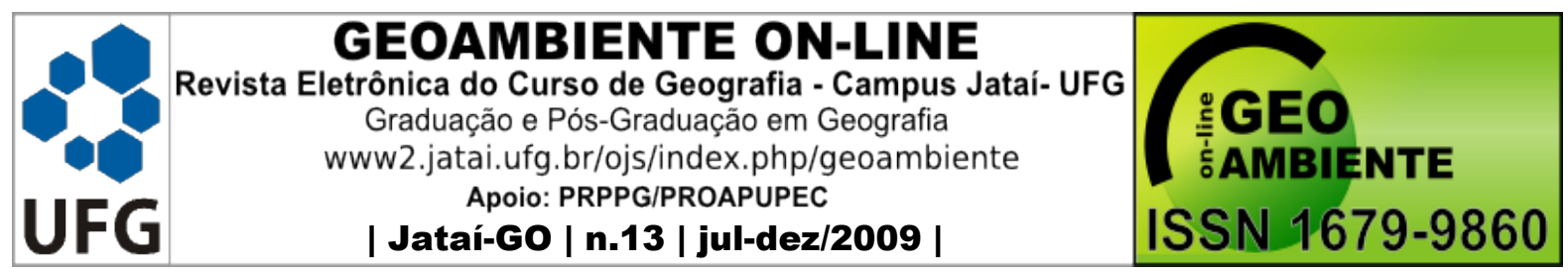

produção... Enfim, podemos passar horas identificando as inúmeras dicotomias com as quais os intelectuais se utilizam para construírem suas pesquisas, modelos teóricos e estrutura de poder na academia. Apesar de estarmos bem entendidos quanto às controvérsias gerados por tal tipo de raciocínio, é indubitável o geógrafo contemporâneo continue a optar pelo estudo superficial, fragmentado, não-múltiplo, rechaçando métodos e abordagens que tentam superar essa problemática, a exemplo da genealogia foucaultiana, da superposição de Willi Bolle, da nomadologia de Deleuze, entre outros exemplos.

A confusão no entendimento da realidade socioeconômica e cultural, fruto de um pensamento calcado no racionalismo positivista - temperado com o "viés de Zoroastro" ${ }^{4}$-, nos dissimula dos micropoderes, dos projetos individuais e coletivos, e das inter-relações que produzem o espaço geográfico e conferem multiplicidade a esta dimensão do social (Massey, 2008).

Essa pequena crítica que levantei é para deixar claro que os estudos das cidades contemporâneas precisam encarar a metrópole como uma "linguagem": uma inscriçãos territorial a ser lida e interpretada, tendo como foco as transformações ocorridas no processo, sempre permanente e contraditório, de apropriação, dominação e uso do espaço.

Para entender este devir, um esforço deve ser feito no sentido de reconhecer e interpretar a reprodução do cotidiano. Entretanto, esse cotidiano não é homogêneo, coisificado, e tampouco estável: compõe-se de ambigüidades, interconexões, hierarquias e identidades socioculturais e territoriais.

Enfim, não podemos analisar a metrópole como um sistema rígido, imóvel, onde o espaço é apenas reflexo ou um produto estandardizado das relações sociais. A metrópole é, antes de tudo, uma totalidade, ou ainda, um conjunto de múltiplas totalizações processadas no espaço geográfico, e são essas totalizações que deliberam os conflitos que se dão na

\footnotetext{
${ }^{4}$ Zoroastro - conhecido também como Zaratrusta pelos gregos - foi um sábio de origem persa que sistematizou um complexo dualismo de abrangência metafísica (a crença em dois princípios co-eternos, incompatíveis e antagônicos: o reino do céu e o reino das trevas), cosmológica (criação-anticriação), ética (bem-mal) e antropológica (corpo-espírito). Este dualismo radical influenciou o pensamento grego e se disseminou por mundo afora, e até hoje se faz presente no pensamento ocidental.

${ }^{5}$ Faço uma analogia ao método etnográfico utilizado pelo antropólogo norte-americano Clifford Geertz (1989).
} 


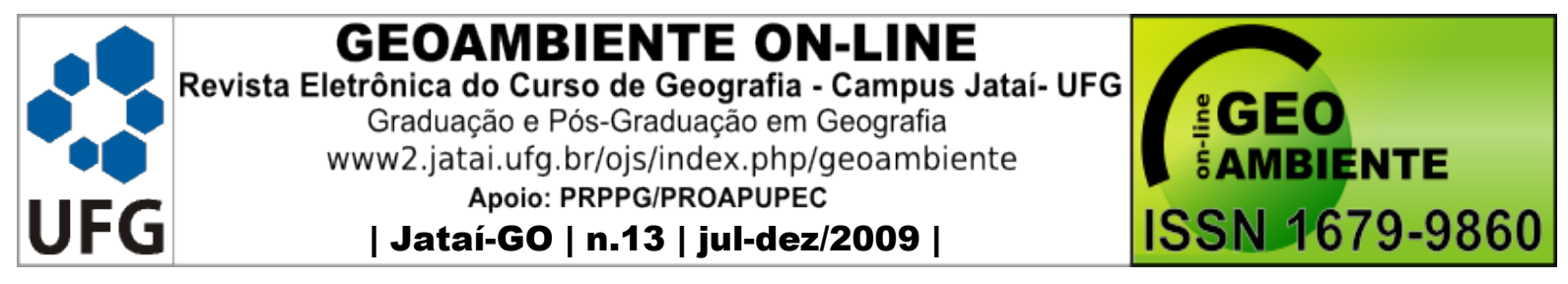

territorialidade dessas totalidades ${ }^{6}$. São esses conflitos dão o norte para reconhecermos a crise estrutural. Ao longo do texto, essa crise será tratada como crise urbana.

Esse sistema, por sua vez, precisa estar constantemente acessando os seus dispositivos de segurança para intervir nos conflitos que, porventura, desnivelem os estratos sociais cimentados, estáticos. A busca então é pela disciplinarização dos corpos selvagens, que são mal in-formados pela estrutura social (FOUCAULT, 2007). Essa prática social, que configura uma relação de poder (Ibid.), visa à obtenção de segurança.

Destaca-se que o poder, por ser multidimensional, e estar espraiado entre os "poros" da sociedade, faz-se onipresente e onipotente em todas as esferas do socius, prescindindo a lógica da distribuição dos objetos e o controle das práticas sociais que aí decorrerão.

Discutir o poder (e os poderes) na metrópole contemporânea é um desafio nada amistoso, uma necessidade que advém do desafio inadiável “[...] do enfrentamento político da rudeza da realidade social e da alienação cultural que o ordenamento territorial globalizado impõe" (BARBOSA, 2006, p. 144).

Este choque de globalização(ões) vem transformado fenômenos rivais, inicialmente de lugares diferentes, em fenômenos locais que precisam ser abordados à luz do entendimento das dinâmicas agenciadas pelos homens e mulheres urbanos. Não podemos falar de uma única globalização, mas de múltiplas globalizações que geram distintos modos de produção, regiões, territórios, paisagens, conflitos endógenos, etc.

O território é um dos conceitos-chave a ser utilizado para dar conta desses múltiplos processos geográficos engendrados na metrópole. Essas dinâmicas são, pela essência dialética delas, catalisadoras de conflitos e formadora de (contra)poderes anexados às relações sociais, portanto, a relevância em abordá-lo antes de seguir em frente. Serão verificadas as mudanças ocorridas no âmbito do Estado e da reestruturação produtiva, remanejando os lugares e afirmando a metrópole como o centro da economia e do social.

Nas próximas páginas, abordaremos as conseqüências de um tempo em que a ingovernabilidade surge como "idéia-força", portanto devemos tratá-la para aniquilar as conotações equivocadas que esse termo supõe (pegamos a metrópole do Rio de Janeiro para

\footnotetext{
${ }^{6}$ Buscamos essa idéia em SILVA (2001).
} 


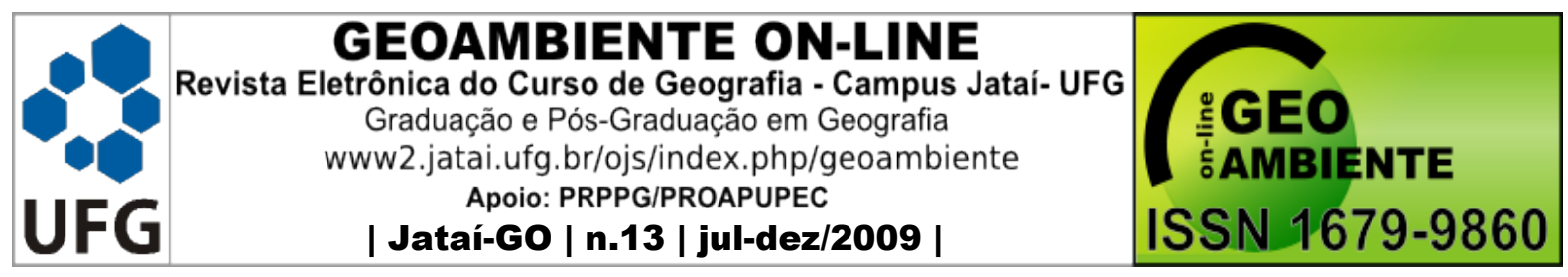

exemplificar as questões). Por conseguinte, traduziremos o que é a "crise do homem urbano" e os conflitos que engendram os diversos poderes e contextos sociais nos ambientes urbanos.

Assim sendo, buscar os vetores de legitimação da ordem vigente $\mathrm{e}$ as territorialidades diferenciais dentro do cenário sumariamente estanquizado das sociedades urbanas ocidentais será o foco da nossa atenção.

\section{2 - Território e territorialidade(s): apontamentos}

Já é de conhecimento do geógrafo que, para o espaço urbano-metropolitano se tornar inteligível, é imprescindível investigar os processos espaciais de apropriação, dominação e re-significação a partir do movimento histórico e da simultaneidade de eventos que o caracterizam. O território e a territorialidade configuraram-se recentemente em conceitos geográficos que aprofundam o debate em torno das relações de poder nos interstícios da vida urbana, a forma como ele se "materializa" e se perpetua na cidade.

Por serem conceitos de grande apelo discursivo - não à toa, estão presentes hoje no discurso de outras ciências (Sociologia, Antropologia, Demografia, Economia, Psicologia, Comunicação Social) -, seu tratamento vem igualmente sofrendo problemas e outros encalços. Por isso, vejo-me na necessidade de fazer um breve comentário sobre os autores em que me referencio para a discussão de território e territorialidade.

Raffestin (1993) é um deles. Ele foi um dos primeiros geógrafos a tratar estrategicamente dessa categoria, procurando enfatizar o caráter político-estratégico e as relações de poder disseminadas dentro dessa delimitação espacial. O poder seria intrínseco ao território, advindo que uma comunidade política carece de uma centralização de poder para a sustentação da estrutura socioespacial, logo, ele não precisa de justificativas, ele se autolegitima.

Raffestin afirma que:

[...] o território se forma a partir do espaço, é o resultado de uma ação conduzida por um ator sintagmático (ator que realiza um programa) em qualquer nível. Ao se 


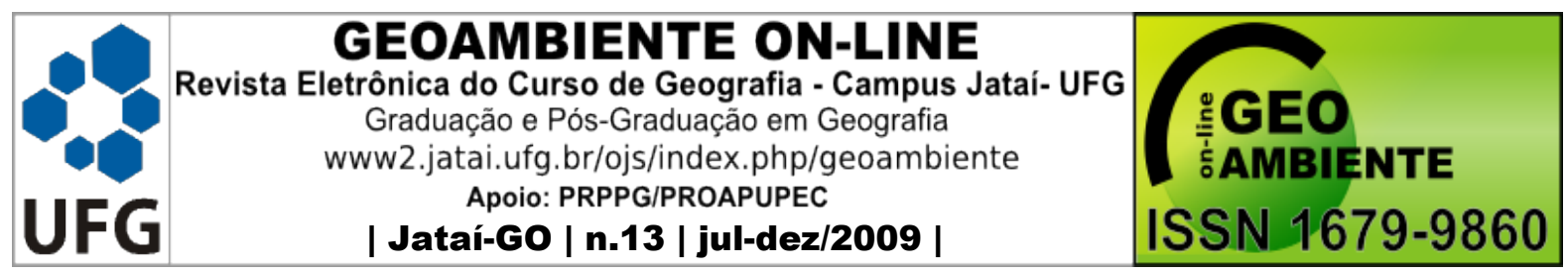

apropriar do espaço, concreta ou abstratamente [...], o ator "territorializa" o espaço. (RAFFESTIN, 1993, p. 143).

Influenciado pelo pensamento Lefebvriano, ele afirma que o espaço é anterior ao território, e é nesse espaço "territorializado" que há uma relação social, com as suas conflitualidades espacialmente delimitadas.

O território não poderia ser nada mais que o produto dos atores sociais. São eles que produzem o território, partindo da realidade inicial dada, que é o espaço. Há portanto um "processo" do território, quando se manifestam todas as espécies de relações de poder [...]. (RAFFESTIN, 1993, p.7-8).

Para ele, o território não é um mero reflexo social, mas antes, relações sociais que se territorializam diferencialmente, marcadas pelo poder que é construído via trabalho material e imaterial. Cada organização para ele, "procura reforçar sua posição obtendo trunfos suplementares, de tal modo que possa pesar mais que outras na competição" (p. 59).

É importante destacar que Raffestin já identificava a rede como um elemento importante, diluído no território, onde desenharia um sistema de linhas que registraria, ora o fortalecimento interno dos territórios, ora o avanço dessas linhas para fora dos limites do território, desestruturando as bases da integração. Ao citá-lo, Haesbaert (2006b, p. 57) comenta que "[...] Raffestin defende a idéia da rede como uma das "invariáveis" constituintes do território, juntamente com os nós ou pólos e as malhas (ou tecidos)".

Devido à sua concepção materialista, afora ter desdobrado as duas faces da constituição do território (uma material e outra imaterial) e suas trocas mútuas, ele não mostrou como se efetiva o processo espaço-territorial. Deste modo, o conceito foi reificado, negligenciando o campo de forças e de possibilidades introjetados na relação sociedade $\mathrm{x}$ espaço.

Souza (1995) define o território como "um espaço definido e delimitado por e a partir de relações de poder" (p. 78). O poder seria inerente a qualquer comunidade política, dado que é imprescindível que aja uma "soberania" para gerenciar os interesses comuns e que nada fuja do padrão preestabelecido pela comunidade, entretanto, o poder, 


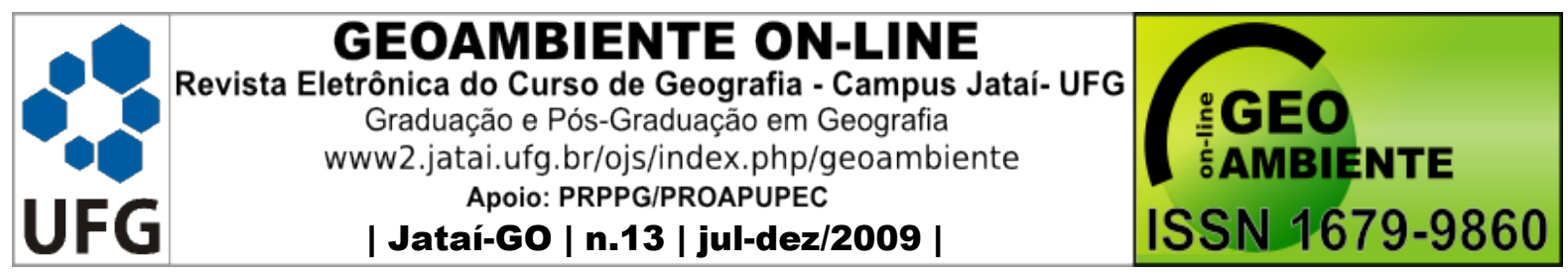

quando está em vias de se obliterar, ele é passado para o segundo plano, com a violência tomando as rédeas até que o poder seja posto de volta ao seu devido lugar?

A abordagem territorial de Souza é política e cultural também, visto que ele identifica e delimita no espaço urbano territórios das mais variadas espécies: territórios formados por identidades culturais, pelas minorias étnicas e/ou racistas, pela prostituição, tráfico de drogas, moradores de rua, seguido dos territórios mais extensos, como o de uma grande metrópole ou um aglomerado urbano, e por fim, os imensos blocos territoriais, como o constituído pelos países membros da OTAN.

Sua crítica à posição de Raffestin decorre daquilo que afirmei anteriormente: A falta de coerência no exame do território num sentido relacional.

Explicando melhor, Souza afirma que:

Ao que parece, Raffestin não explorou suficientemente o veio oferecido por uma abordagem relacional, pois não discerniu que o território não é o substrato, o espaço social em si, mas sim um campo de forças, as relações de poder espacialmente delimitadas e operando, destarte, sobre um substrato referencial. (Sem sombra de dúvida pode o exercício do poder depender muito diretamente da organização espacial, das formas espaciais; mas aí falamos dos trunfos espaciais, e não do conceito de território em si). (SOUZA, 1995, p. 97).

Haesbaert (2006c) irá muito além das concepções naturalistas, economicistas e jurídico-políticas do território, criando um debate em torno da concepção de multiterritorialidade, esta que, nas suas múltiplas dimensões, é o alicerce para o entendimento das práticas socioespaciais, que são complexas e multifacetadas.

Simplificadamente, o esquema territorial (“tipo-ideal”) é:

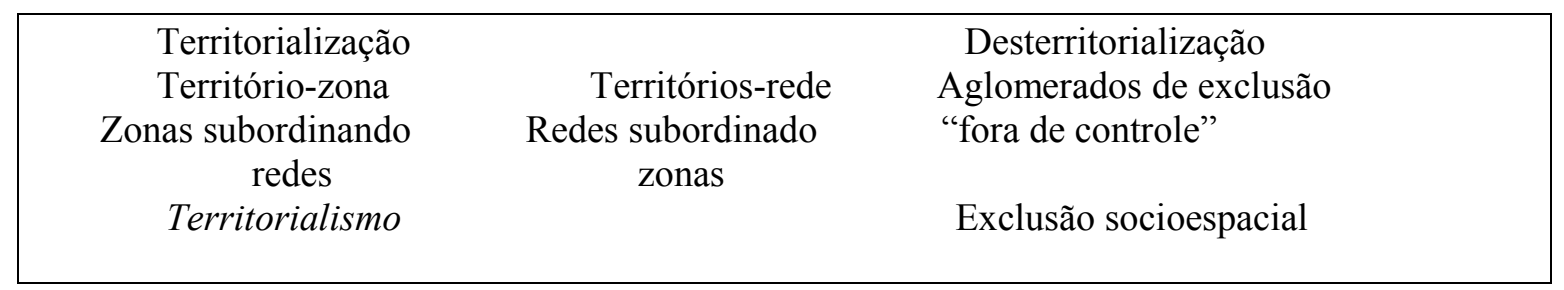

Quadro 1: Baseado em Haesbaert (2006c).

\footnotetext{
${ }^{7}$ Para melhor entendermos as concepções de poder, violência, dominação, etc. ver ARENT, H. $A$ condição humana. Rio de Janeiro, Forense, 1981.
} 


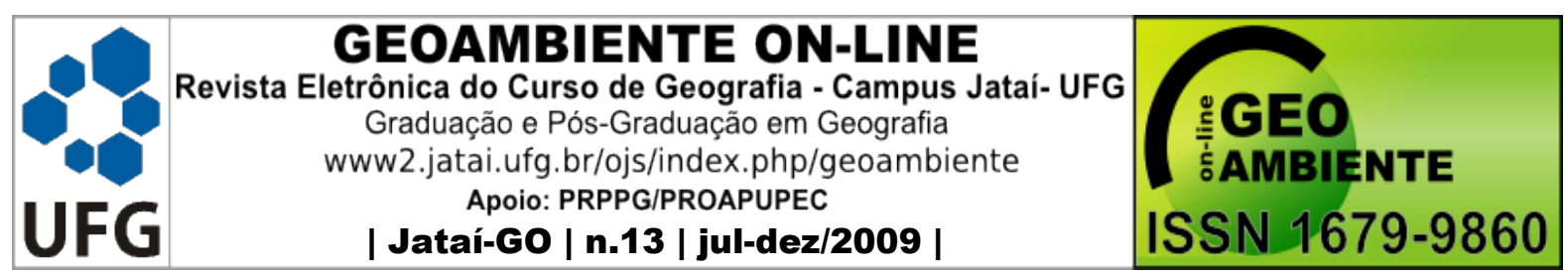

Para ele, o território "[...] define-se antes de tudo com referência às relações sociais (ou culturais, em sentido amplo), em que está mergulhado, relações estas que são sempre, também, relações de poder" (HAESBAERT, 2006b, p. 54).

$\mathrm{O}$ poder precisa ser entendido dentro da perspectiva histórica, pois a configuração dele não é a mesma para todos os tempos. Dependendo da época e do contexto, ele se metamorfoseia, não tirando, entretanto, a sua validade e vitalidade. Assistimos hoje, a um poder que emerge e se corrobora na produção de símbolos, no imagético-discursivo, na virtualidade do ciberespaço, na alienação cultural dos desterritorializados "por baixo", etc, enfim, um poder que se autentica no viés simbólico-cultural, sendo catalisado pelo/no espaço e transformado em estratégias de dominação e controle dos territórios.

Entendendo a atual dinâmica do meio técnico-científico informacional, o autor conclui:

[...] o próprio território se torna muito mais complexo, múltiplo, por um lado mais híbrido e flexível, mergulhado que está nos sistemas em rede, multiescalares, das novas tecnologias da informação e, por outro, mais inflexível e fechado, marcado pelos muros que separam ricos e pobres, grupos "mais" e "menos seguros", mais e menos territorializados. Haesbaert (2006b, p. 65).

Haesbaert propõe analisar a desterritorialização dentro das perspectivas econômica, política e cultural. Estas dimensões estão interligadas e dialogando constantemente através da tríade T-D-R (territorialização, desterritorialização e reterritorialização). Com isso, enfatizam-se os limites e as inter-relações, bem como o ciclo de informações (inovação, difusão e obsolescência - IDO) que marcam as sociedades urbanas modernas, revelando a instabilidade dos significados e das inovações materiais.

Hoje, muito mais que a destruição de territórios, devemos destacar a forma como os indivíduos e grupos conseguem acessar e articular vários territórios ao mesmo tempo. A este processo, Haesbaert denominou de multiterritorialidade (Idem).

O apanágio da relação sociedade-território, portanto, seria a apropriação simbólica que as pessoas têm com a porção de espaço re-territorializada, gerando um sentimento de 


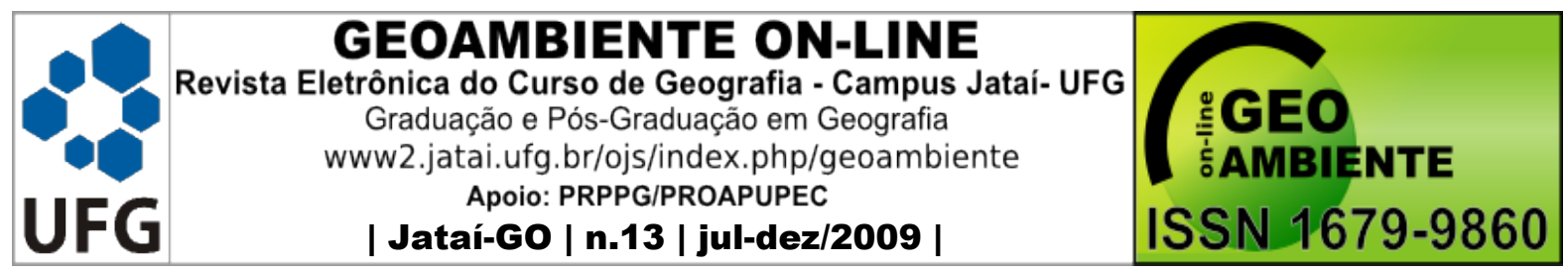

pertencimento que dá às práticas sua importância particular, ora reivindicando autonomia ou servindo aos interesses mais globais ditados pelos "de fora".

Gomes (2002), que possui uma linha de raciocínio calcada em práticas "geopolíticas" na cidade, assegura que: "o território é, pois, neste sentido, parte de uma extensão física do espaço, mobilizada como elemento decisivo no estabelecimento de um poder" (GOMES, 2002, p. 12). O efetivo controle do espaço, alicerçado no poder (político) aí instaurado são as prioridades de sua análise.

Territorializar seria então, para Gomes:

[...] o movimento de um agente titular no ato de presidir a lógica da distribuição de objetos sobre uma dada superfície e de, simultaneamente, controlar as dinâmicas que afetam as práticas sociais que aí terão lugar. (GOMES, 2002, p. 12).

O autor cita ainda o fato de que muitos geógrafos ainda confundem a noção de território com a dimensão emotiva, identitário-cultural: elas situar-se-iam como parte da estratégia para o estabelecimento, manutenção e reforço do poder, e não como o território/territorialidade em si.

Neste raciocínio, Gomes objeta também o uso do conceito de apropriação, vide que:

[...] esta última pode ser construída a partir de múltiplos veículos, imaginário, sentimentos, posse, propriedade, uso, sem que nenhum deles signifique sempre o exercício efetivo de um controle sobre os objetos e as práticas sociais que aí ocorrem. (GOMES, 2002, p. 12-13).

Como vimos, distintas concepções de território e territorialidade impregnam o raciocínio dos geógrafos. Cabe a nós, despidos de quaisquer pré-conceitos e dogmas, selecionar o(s) melhor(es) argumento(s) e utilizá-los da melhor forma possível em nossas análises e contextos de estudo.

Contudo, além da polissemia, essa breve introdução serviu para ratificarmos que a desterritorialização, muito mais que a "perda efetiva" do território, contempla uma relação de transformação de algo. Toda desterritorialização implica em (des)reconstrução de outros territórios, aparecendo como um elemento multiplicador de situações que se correlacionam 


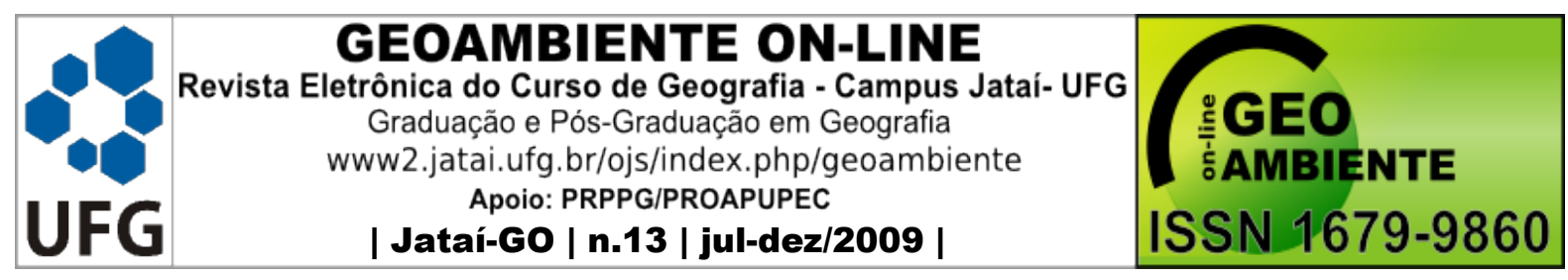

e que correspondem ao contexto histórico. Neste caso, a desterritorialização que está em vigor é o indicador de um processo que fomentado pela lógica econômica burguêscapitalista: a exclusão e/ou contenção socioespacial.

$\mathrm{Na}$ quase totalidade desses processos, a des-territorialização dos grupos/classes menos favorecidos (ou em nada favorecidos!) se dá de forma precária, excludente, restando a estes despossuídos, como únicas armas, seus corpos (mão-de-obra) e as permanentes reinvenções (sociais, culturais, religiosas) típicas de uma ordem estruturada na contraditoriedade, projetando novas luzes e geografias de solidariedade e esperança.

\section{3 - As mudanças do séc. XX e os novos atributos da/na metrópole contemporânea}

O lugar seria o espaço de encontro dos indivíduos para exercer a política, é o espaço público ao qual tanto aludimos na literatura científica e em nossas utopias particulares, onde pegamos o pensamento da pólis grega, a cidade que foi, até os nossos dias, uma cidade sui generis no exercício da política e da igualdade dos indivíduos perante o espaço público. Mas hoje observamos que esse espaço público está longe de ser um espaço de e para todos. Sua estrutura está abstrata e concretamente estilhaçada, sendo "privatizada" para os atores hegemônicos, restringindo destarte, os espaços da cidadania a extensões cada vez mais diminutas e liminares.

O discurso dos políticos, cientistas e do próprio senso comum é o discurso da desordem, da perda do espaço público, da falta de regras de sociabilidade, da perda de valores, da aculturação dos indivíduos pela mass media e, enfim, da precarização trabalho.

Em relação a esse último caractere, destaca-se que os indivíduos, cada vez mais, abrem mão dos seus direitos frente à flexibilização do mercado de trabalho, que sem precisar de justificativas, inclui seus empregados de maneira precária e temporária. A falta de condições para o crescimento cognitivo dessas pessoas e a garantia da demissão após a realização eficiente da mais-valia pelo empregador, põe-las numa situação em que a regra principal é a constante habilitação, dar o "jeitinho brasileiro" para ingressar nessa nova ordem, alocadora de tecnologias e gestões empresariais a cada dia mais complexas e excludentes. 


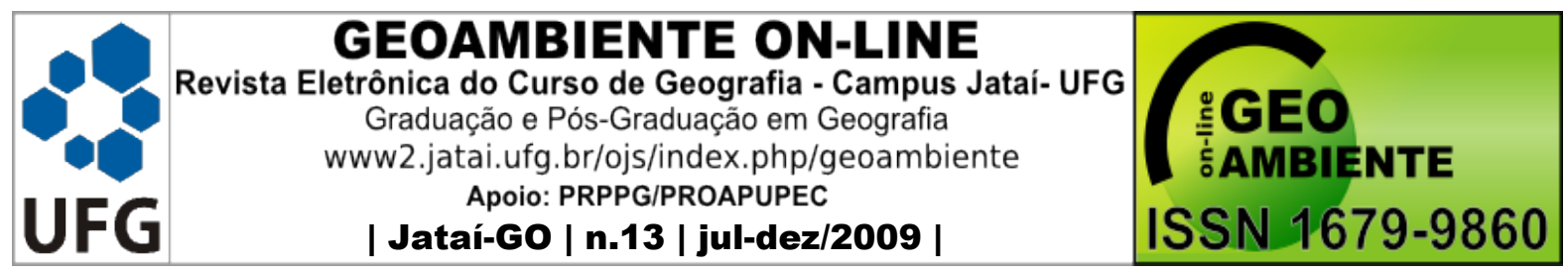

A acumulação flexível, resposta do capitalismo para a crise dos anos 70 , foi uma série de procedimentos que visavam o desmantelamento do rígido e limitado sistema de produção e consumo que era o sistema fordista, sendo o carro-chefe da nova lógica de reprodução ampliada do capital. "Aqui, a acumulação flexível parece enquadrar-se como uma recombinação simples das duas estratégias de procura de lucro (mais-valia definidas por Marx)." (HARVEY, 2006, p. 174). E ele diz mais:

Ela também envolve um novo movimento que chamarei de "compressão do espaçotempo" no mundo capitalista - os horizontes temporais da tomada de decisões privada e pública se estreitaram, enquanto a comunicação via satélite e a queda dos custos de transporte possibilitaram cada vez mais a difusão imediata dessas decisões num espaço cada vez mais amplo e variegado. (HARVEY, 2006, p. 140).

E é nessa nova ordem de acumulação do capital, engendrada pelas grandes corporações industriais, comerciais e bancário-financeiras, que as metrópoles se vivificam e o Estado passa a ter um novo papel, não sendo ele agora mais, um mero gerenciador das relações sociais como era anteriormente: ele se metamorfoseou, e agora é o "grande empresário", o responsável pela integração e modernização dos territórios, ou melhor, a modernização das regiões metropolitanas. Falando a respeito das transformações ocorridas no Brasil nos anos 70, Bernardes (1995) assimilou que a (re) organização do território brasileiro foi forjada para uma adequada transferência geográfica do valor a nível internacional, reiterando o espaço de sua condição frente ao desenvolvimento capitalista desigual.

Essa modernização, que foi na sua essência, uma modernização conservadora, reafirmou os grandes centros urbanos brasileiros como o lócus por excelência da gestão do capital e dos territórios, lugar-chamariz das novidades, do entretenimento, da prestação de serviços, da difusão cultural, etc. Ao mesmo tempo, verificou-se um elevado crescimento de aglomerados urbanos, geralmente perto das metrópoles, servindo vários deles para a relocalização das indústrias e a formação de "bolsões de mão-de-obra".

Por essas questões colocadas, afirmo que o Estado não é, em nenhuma instância, uma forma acabada: é um processo social e territorial, e esse processo que ora tentamos 


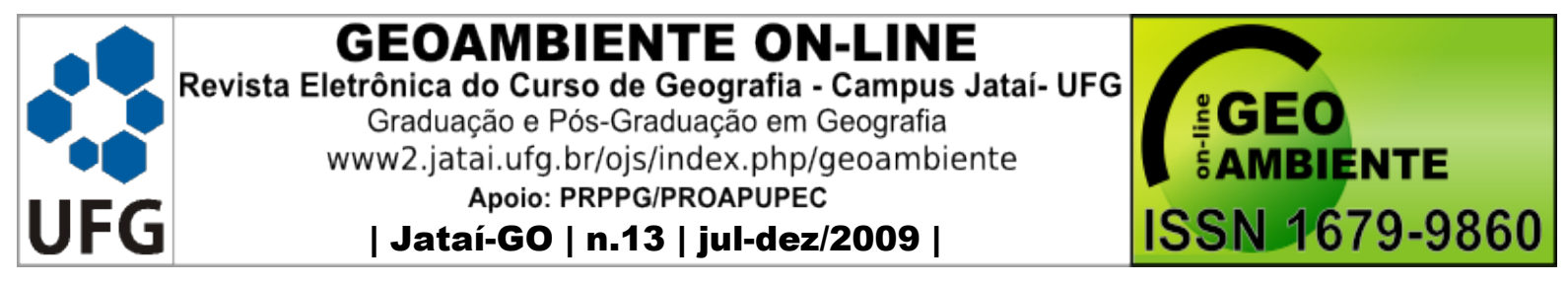

desvendar, tem cada vez mais se clarificado, dado as recentes ações no sentido da desburocratização, privatização e descentralização dos aparatos institucionais do Estado.

A metrópole é a expressão dessas "decupagens", sendo condição, reflexo e produto da modernização, espaço por excelência da territorialização das inovações, das decisões, das grandes firmas multinacionais e dos novos dispositivos de repressão dos conflitos catalisados pelos antagonismos sociais.

Pegando as nomenclaturas de Santos (2001) para diferenciar os territórios, percebemos que a metrópole tem buscado através de modificações na materialidade do espaço geográfico, a condição de serem espaços de densidade, fluidez, rapidez, luminosidade e que comandam outros espaços. Em relação à luminosidade, definida pela acumulação de densidades técnicas e informacionais, a metrópole necessita cada vez mais de ter essa "luminosidade"," se ela pretende ser competitiva nas relações econômicas globais, incluindo aí a atração das atividades "com maior conteúdo em capital, tecnologia e organização" (SANTOS, 2001, p. 264).

Paralelo às considerações supracitadas, devemos asseverar que, diferentemente das concepções de urbanistas e dos políticos-burocratas do séc. XX, a expansão metropolitana não é puramente contígua e padronizada. A ideologia da irradiação das inovações pela core area, onde esta estaria incumbida de levar a modernidade de uma forma segmentada e ininterrupta para todos os espaços por ela encarregados, já está obsoleta, pois é verossímil que as redes, hoje, o vetor capital na difusão da lógica da expansão e reprodução do capital em escala global, asseguram a capacidade de criação e conexão das estruturas fora dos limites físicos limítrofes.

De acordo com Moreira:

As cidades vão se descolando de suas relações regionais para formar um espaço planetarizado, estruturado numa nodosidade em que as cidades articulam-se entre si em rede e com vínculos territoriais cada vez mais imprecisos. (MOREIRA, 2006, p. 82).

\footnotetext{
${ }^{8}$ Não estou aqui adotando uma visão preconceituosa de espaço, na qual a luminosidade seria a única qualificação ideal para o desenvolvimento. A luminosidade significa fins racionais, "uma característica que interessa apenas a um grupo limitado de atores" (SANTOS, 2001, p. 264). Não é a toa que essa característica advoga a ingovernabilidade dos lugares, dado o seu caráter de transcender e excluir os lugares que bem desejar.
} 


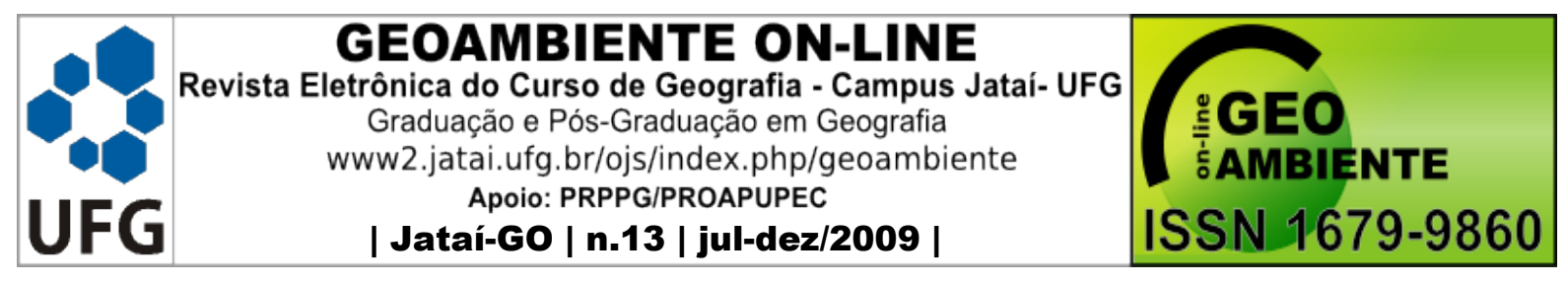

Dessa forma, são criados hiatos espaciais (periferias rurais ou pouco urbanizadas), convivendo com as mudanças privilegiadas de seus "vizinhos" abastados (a metrópole).

A área central abriga em seu seio a constante renovação da sua materialidade e dos segmentos sociais que aí se reproduzem em toda a sua multiplicidade, derivado das modificações culturais, econômicas e políticas que se consubstanciam no espaço social. Ela tem a capacidade de se reordenar territorialmente com antecipação, em vista de possíveis mudanças que possam acontecer na economia global, nos novos artefatos que maximizam os lucros, ou, para fins repressivos, evitar possíveis crises setoriais e/ou a manifestação total da desordem, dado que, até aquele momento, a desordem estava dissimulada por toda a sociedade. Não significa que esses projetos de mudança fortuita sempre tenham eficácia.

A área central reafirma a sua soberania singular, o lócus por excelência das relações sociais e econômicas, concomitante ao detrimento presenciado nas periferias do centro, lugar da obsolescência, mas que por vezes, tem servido para a expansão de edifícios (que não encontraram no core da cidade o crucial "custo-benefício") e o alargamento da oferta de serviços diversos, além de ser o espaço que abriga o "setor de lazer e diversões" da cidade.

Cada indivíduo vivencia a metrópole conforme a sua visão de mundo, contexto situacional, recursos, possibilidades de trânsito, relações estabelecidas etc. Podemos pegar cada indivíduo da grande cidade e veremos quão diferentes são as perspectivas de urbano destes indivíduos, e quão igualmente diferentes são os trajetos, circuitos e atividades por eles praticados.

Pegando o meu exemplo de vivência na área central do Rio de Janeiro, posso fazer uma análise do roteiro que percorro dentro do circuito de lazer e entretenimento da referida área. Sendo feito no período noturno, podemos desvendar os complexos mapas de significados construídos pelos atores sociais que não estão, naquele momento, vinculados à esfera do trabalho, atuando em outras redes, grupos e eventos.

Podemos "experienciar" os circuitos de lazer no centro do Rio de Janeiro à noite indo da Lapa até a periferia de São Cristóvão, sendo esse mesmo trajeto percorrido por inúmeros jovens nos finais-de-semana. O trajeto começa nos bares (Figura 1), restaurantes, 


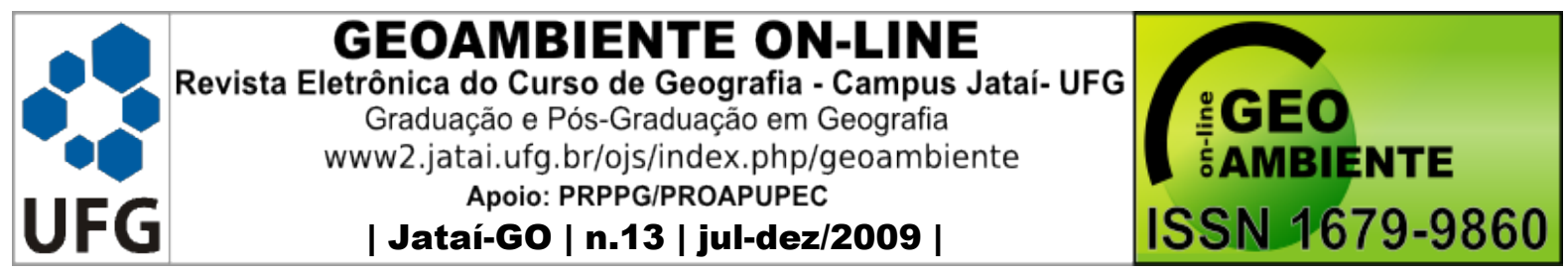

feiras de artesanato e outras atrações na Lapa, ora nos sobrados ou nas imediações compostas de estudantes, estrangeiros, hippies, reggaeiros e outros grupos desviantes. Após um "convênio" entre o poder público e o privado (principalmente empresários ligados às atividades de lazer), os sobrados da Lapa foram restaurados com o fito de incentivar o turismo cultural na área e tornar o lugar mais acessivo, atrativo e "aburguesado", destinados à classe média.

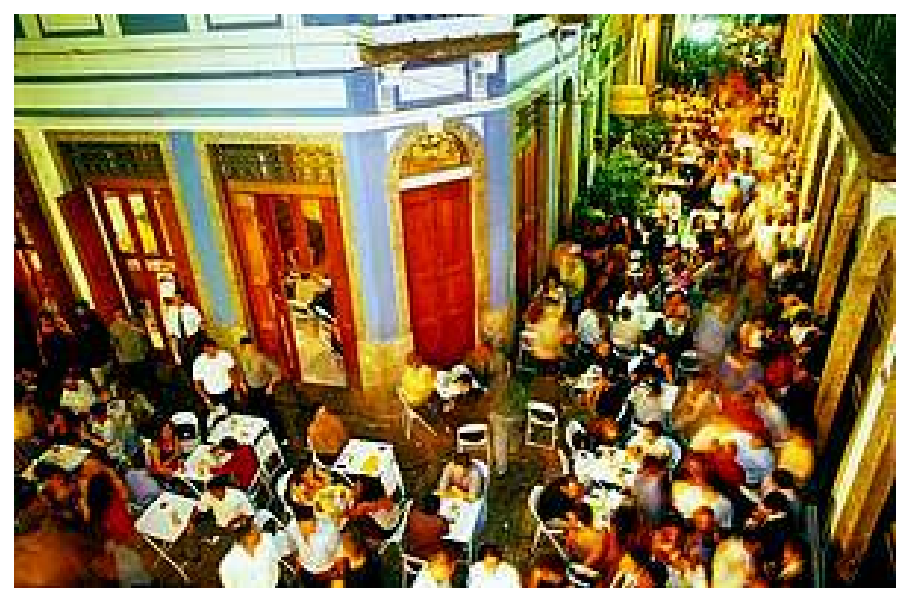

Figura 1: Um dos corredores mais movimentados da Lapa no horário de lazer e de funcionamento das casas noturnas (boates, bares, restaurantes, casas de prostituição). Disponível em:http://semdestino.files.wordpress.com/2008/05/lapa_noite_2.jpg - acesso em: 28/05/2009.

Adiante, podemos ver a Fundição Progresso e o Circo Voador (todos ainda na Lapa), depois passando pelos bordéis e casas de show ao longo da Mem de Sá até chegamos à Rua Ceará, em São Cristóvão, rua esta considerada uma das mais alternativas e marginais do Rio. Em um mesmo lugar, presenciamos grupos de motociclistas, tribos jovens ligadas ao movimento underground', grupos gays, funkeiros, vários bares que procuram atrair consumidores através de músicas pouco convencionais para a cultura dominante carioca; e pro fim, atravessando a Rua Sotero Reis, chegamos à famosa Vila Mimosa, famosa zona de prostituição que, ao contrário do que é pensado no senso comum,

\footnotetext{
${ }^{9} \mathrm{O}$ movimento subcultural underground refere-se às "tribos" e redes de sociabilidade urbanas que participam nos eventos de rock alternativo: são os headbangers, punks, skinheads, emocores, grunges, hardcores, os que intercalam o rock com o ocultismo, com as culturas celta, gótica e outras formas de manifestação estéticoartística e/ou sectarismo.
} 


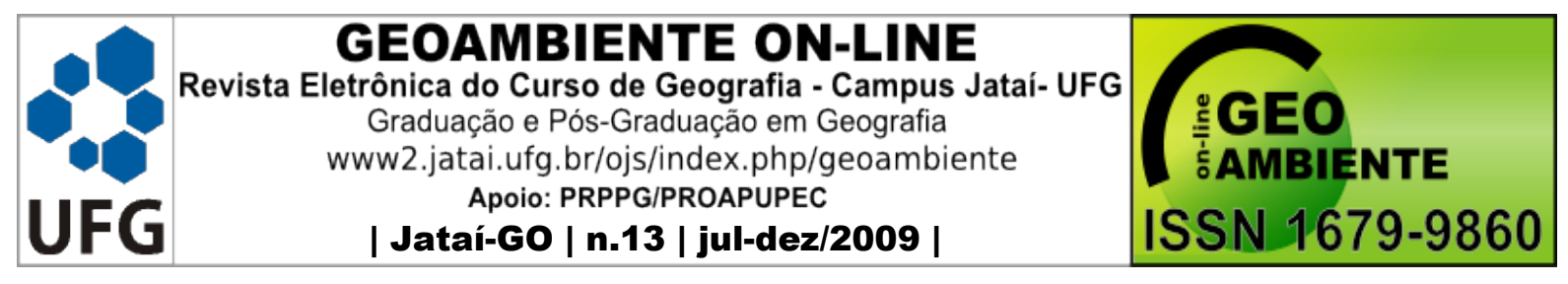

as mulheres e outros agentes ligadas à atividade possuem uma forte organização e dispositivos territoriais para repelir aqueles que, de alguma maneira, ameacem a ordem ali instaurada.

Contudo, os mecanismos de reprodução do estigma e da exclusão social continuam firmemente presentes nas atividades do baixo meretrício.

$\mathrm{O}$ subúrbio $^{10}$ - conseqüência do processo de industrialização desenfreado e do contingente demográfico que excedeu, mas mesmo assim, a cidade o absorveu -, luta pela renovação constante dos seus lugares e por políticas que adrede liminarizam os espaços. Toda essa complexidade que ousamos abarcar tem em seu arcabouço a técnica como um elemento primordial da estruturação do espaço geográfico (SANTOS, 1996).

A técnica está cada vez mais científica e dotada de uma intencionalidade (Ibid.), dando uma racionalidade ao espaço que o torna potencialmente autônomo, preparado para responder aos interesses de quem o instituiu. Ante o exposto, Santos (Ibid.) assinala a transformação do meio geográfico (ou natural) para um meio técnico-científico informacional.

Dentro dessa racionalidade do espaço, um dos objetivos da sua fundação é reprodução as hegemonias sociais em todos os níveis. Os espaços liminares (BARBOSA, 2006) são uma das possibilidades deste espaço racional, restringindo o acesso de outsiders através da promoção de uma cidadania particularista, isto é, restrita aos muros e grades dos condomínios fechados, dos prédios, dos resorts e dos shoppings luxuosos. Com isso, se esfacela grande parte do espaço público, engendrando uma espécie de "neofeudalismo" na metrópole contemporânea onde o perigo e a insegurança estão por toda parte, enquanto que a ordem, a segurança e a paz estão circunscritas dentro das fortalezas construídas pelos established.

Esse embate territorial nas cidades leva-nos adrede a uma sociedade indiferente, que não reflete sobre as suas próprias estruturais conceituais e as práticas envolvidas na

\footnotetext{
${ }^{10}$ Coloco o termo subúrbio em seu significado tipicamente "carioca", como sendo a periferia distante do centro e local de residência dos trabalhadores. No imaginário de seus habitantes, eles não pertencem à cidade no sentido amplo do termo.
} 


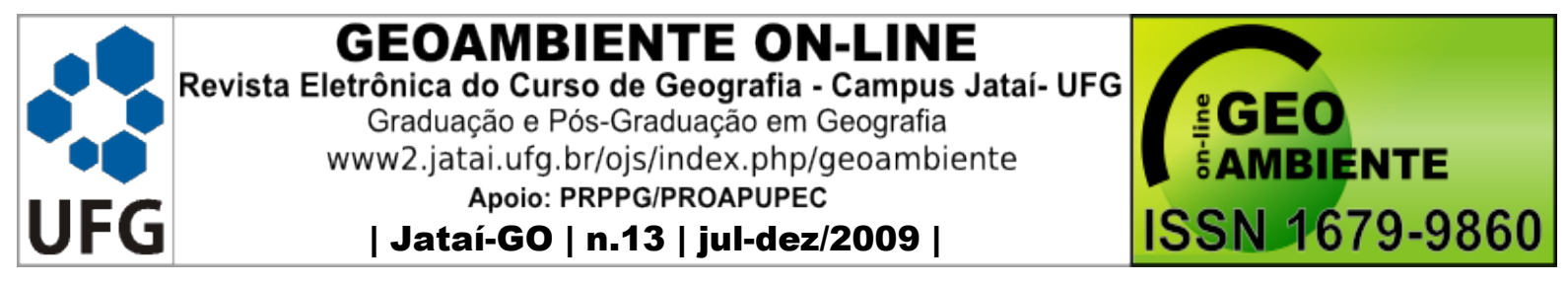

legitimação das redes do poder. Em suma, a sociedade civil está engessada, apresentando fragilidade no exercício da alteridade e da igualdade no espaço público.

A técnica empreendida na metrópole contemporânea é indiferente para com o meio em que se instala. Baseado nisso, podemos entender porque as técnicas atuais não necessitam compor a priori com a herança histórico-cultural. O espaço metropolitano, portanto, se caracteriza pelo uso fragmentado e articulado que do solo urbano, sendo dotado de uma racionalidade técnico-instrumental e atendendo às intenções dos agentes que o instalaram.

Para o autor, "o papel dos macrossistemas técnicos, indispensáveis nesta fase de globalização, é crucial na explicação da tendência à racionalização das cidades" (SANTOS, p. 306). São estes elementos, compostos pela racionalização do espaço, que perfilham e impõem as novas normas, regras, condutas e valores na sociedade.

Portanto o espaço racional caracteriza-se como "uma resposta pronta e adequada às demandas dos agentes, de modo a permitir que o encontro entre a ação pretendida e o objeto disponível se dê com o máximo de eficácia. Esta tanto depende da técnica contida nas coisas e nas ações. (Idem, 2006, p. 300).

Esses são os novos "paradigmas" da metrópole, não esquecendo que o uso da palavra paradigma não está aqui sendo utilizada para enfatizar que há somente "uma" leitura das cidades. Inúmeros outros paradigmas podem ser evidenciados pelos cientistas, apontando (velhas) novas possibilidades de coexistência da multiplicidade no espaço (MASSEY, 2008). Com efeito, sigo as palavras de Haesbaert:

A cartografia da metrópole moderna é, portanto, muito mais rica e controversa do que nossos genéricos modelos podem supor. Além da grande diferenciação no tecido urbano, que cria espaços singulares, e da distribuição desigual dos equipamentos e serviços, e para além desta configuração física, há uma complexa rede de relações entre grupos que traçam laços de identidade com o espaço que ocupam, criam formas de apropriação e lutam pela ocupação e garantia de seus territórios. (HAESBAERT, 2006a, p. 93). 


\begin{tabular}{|c|c|c|}
\hline U & \begin{tabular}{|c|} 
GEOAMBIENTE ON-LINE \\
Revista Eletrônica do Curso de Geografia - Campus Jatai- UFG \\
Graduação e Pos-Graduaçăo em Geografia \\
www2.jatai.ufg.br/ojs/index.php/geoambiente \\
Apoio: PRPPG/PROAPUPEC \\
| Jataí-GO | n.13 | jul-dez/2009 |
\end{tabular} & $\begin{array}{l}\text { :GEO } \\
\text { ISSN } 1679-9860 \\
\text { ISAMBIENTE }\end{array}$ \\
\hline
\end{tabular}

\section{4 - O espectro da "ingovernabilidade" nas metrópoles: uma necessária reflexão} teórica e alguns exemplos

Quando abordamos o termo ingovernabilidade, nos damos conta de que essa expressão se tornou polissêmica, dada a sua abordagem ser feita por pesquisadores de ciências diversas e, principalmente, pela mídia, grande utilizadora de "idéias-força" para pasteurizar e descontextualizar os temas que deveriam estar na ordem do dia. A categoria (in)governabilidade sofreu um "rapto ideológico", no sentido dessa categoria ter sofrido mudanças em seu significado. Esse rapto deflagrante do significado das categorias ocorre justamente nos momentos de crise e/ou ruptura histórica e social. Surge daí, a necessidade de se criar categorias político-ideológicas que dêem conta de amenizar os pavores de uma possível obliteração no tecido sociopolítico-espacial.

Souza (2000) nos chama a atenção para a discussão verdadeira da ingovernabilidade e do atual modelo de democracia: a democracia representativa.

A ingovernabilidade sugeri que algo é ou está ingovernável. Souza (2000) alertounos quanto a essa característica, e ele recorda o apontamento de Leila Frischtak para os equívocos que essa expressão vem sofrendo: “A governabilidade é, na verdade, um atributo daquilo que se governa (ou melhor, ainda seria dizer, daqueles que são governados), isto é, da própria sociedade" (SOUZA, 2000, p. 223).

Ela é, antes de tudo, uma questão social.

A ingovernabilidade é o devir das causas e efeitos que estão na ordem social do dia, não se restringindo aos problemas institucionais (do aparelho estatal). A ingovernabilidade, portanto, engloba tudo: desde o tráfico de drogas e a criminalidade, passando pela ocupação imprópria de terrenos, o processo de favelização, a especulação imobiliária, e porque não também, a "privatização" dos logradouros públicos para formação dos condomínios exclusivos, o fechamento de ruas nos bairros elitizados? As classes médias e altas também estão incluídas no rol das características que aludem à ingovernabilidade.

Isso tudo é a materialização dos problemas que derivam de uma gestão pública ineficiente e dissimuladora das contradições sociais. Dado esses fatos, a ingovernabilidade 


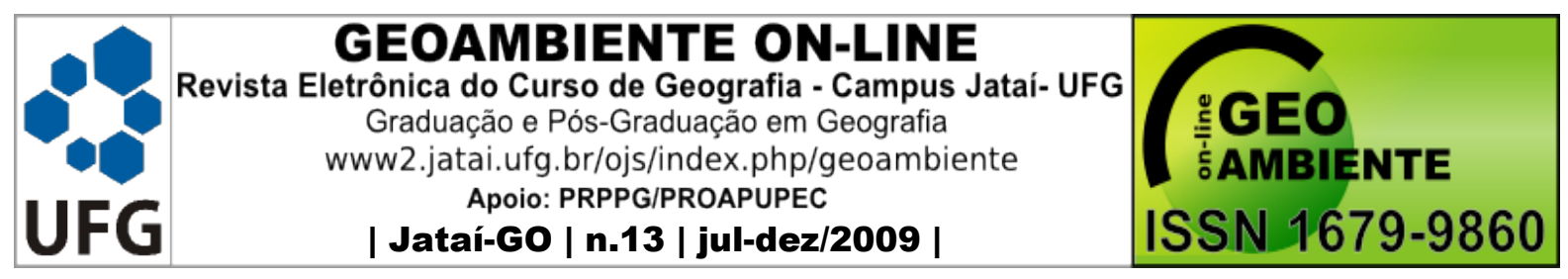

não pode ser olhada com preconceito, visto apenas como o corolário dos menos favorecidos, atribuir o fracasso da gestão às classes baixas.

A ingovernabilidade urbana nos abre a perspectiva de ampliarmos o nosso horizonte intelectual e pensarmos em outros modelos de civilização, desenvolvimento e gestão sócioterritorial que não os que estão em vigor, devido a estarem defasados, insuficientes, inadequados para suprir os dilemas mais básicos da sociedade. A ingovernabilidade chega a ponto de colocar em jogo o próprio sentido usual da cidade (unidade na diversidade, uma configuração geográfica coerente), posto que a fragmentação sociopolítico-espacial a qual assistimos nas metrópoles contemporâneas - especialmente nas metrópoles dos países periféricos e semiperiféricos - é terrificante, onde as pessoas passaram a negar total ou parcialmente o "outro" (visto que há interesses em jogo) na criação e reprodução do seu cotidiano. Deixemos que Souza finalize o assunto:

[...] mas que simplesmente um padrão mais complexo de segregação; o que vai se gerando é uma espacialidade caracterizada por sérios conflitos e tensões, pelo desafio ao Estado e ao controle territorial estatal representado por grupos criminosos e pelas estratégias espaciais defensivas utilizadas por parcelas das camadas médias e altas da sociedade. (SOUZA, 2000, p. 217).

Não podemos comparar as world cities do Primeiro mundo com as metrópoles "periféricas".

O Rio de Janeiro, a despeito de ser uma metrópole "globalizada" e cosmopolita, apresenta agudos problemas na sua estrutura socioespacial. Por exemplo, de um lado, há a proliferação dos enclaves territoriais, controlados por bandos criminosos (Terceiro Comando, contra Comando Vermelho e esses dois contra os grupos menores), milícias, e políticos praticantes do clientelismo privado. Do outro lado, vemos uma elite, assustada com uma situação de desordem que, em grande parte, ela mesma criou e tenta fugir das conseqüências: procura por espaços novos para construir seus edifícios-fortaleza e "castelos neofeudais" (os condomínios fechados) em plena metrópole.

Barra da Tijuca, Zona Sul e alguns corredores da Zona Norte e Oeste (Méier, Del Castilho, Campo Grande) do Rio de Janeiro mostra-nos como se dá a junção das iniciativas 


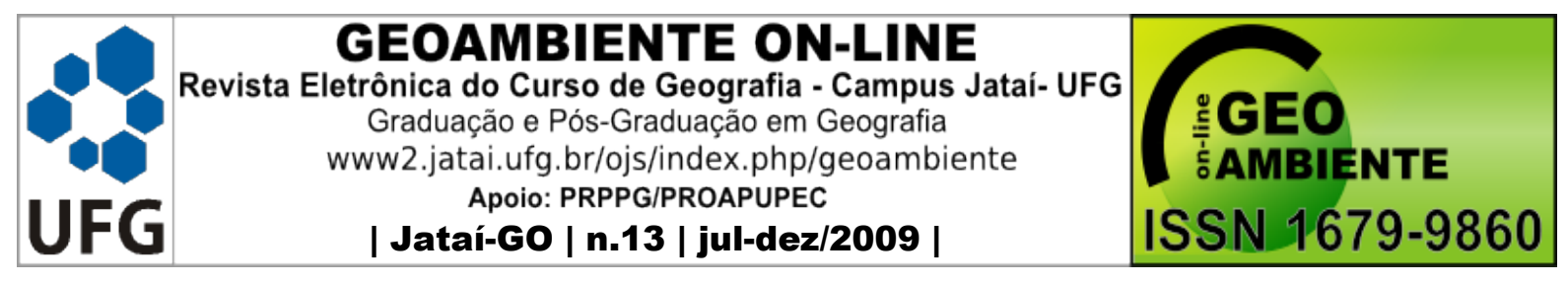

pública e privada: agindo conjuntamente, criaram uma forma de não vender uma casa ou apartamento apenas, e sim, vender todo um urbanismo, um novo estilo de vida, lugar onde o espaço público é verídico.

Sobrou assim, para os espaços do "resto" da cidade, a condição de serem apenas espaços coletivos, onde a circulação das pessoas dá-se apenas para o trabalho ou fins que individuais. Esses espaços são quase totalmente despidos de política, “dominados" pelos moradores de rua, gangues rivais, prostituição, tráfico de drogas, etc. Em suma, a sociedade está imersa numa fragmentação do seu tecido sociopolítico-espacial (Idem).

\section{5 - A crise do "homem urbano", os "(contra) poderes" e a busca de contextos alternativos na cidade}

As metrópoles atravessam hoje um momento único e delicado, traduzido na complexificação das relações sociais, cada vez mais complexas e fragmentadas, e o Estado e o seu (re) ordenamento territorial urbano são chamados para uma missão: apaziguar as crises e conflitos que se instalam no espaço urbano, momento esse que nos mostra a totalidade em cisão, a época de mudanças, a ocasião em que o Estado e as elites dominantes conseguem as justificativas e a legitimação para utilizar os seus instrumentos de coerção. Essa intervenção, dado o seu grau de freqüência alto, acaba por se configurar numa banalidade, pois a sociedade urbana a assimila sem muito questionamento e acaba por ver nesse sistema coercitivo uma coisa "normal" e até benéfica para suas vidas.

Torna-se visível que a sociedade urbana é cada vez mais, uma sociedade que se coisifica, que é reificada nas suas relações, ignorando as pressões que vem de "cima".

Temos aí a constatação que, apesar de parecer óbvio, permite esclarecer as desigualdades espaciais através dos poderes que se fazem presentes no interior da sociedade, que agem muito sutilmente e usam da força apenas em casos extremos.

O Estado é a institucionalização do poder, aquele que monopoliza a violência legítima. Sua capacidade de agir em nome dos cidadãos é única, soberana. Atualmente, soa 


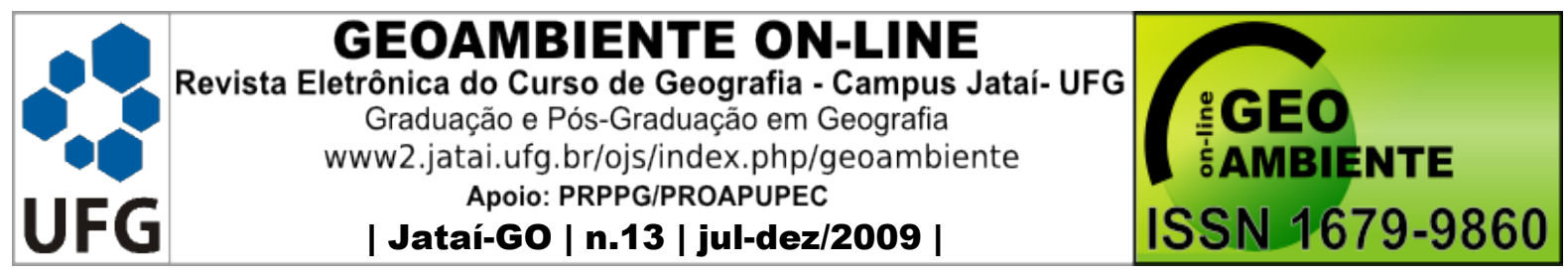

como o salva-vidas da desordem, da insegurança urbana, arcando o ônus de uma ordem elitista que faz de tudo para manter sua estabilidade e influência.

Numa excelente síntese de Dallari sobre o poder, o autor destaca que:

O poder, reconhecido como necessário, busca legitimidade, que é obtida com o consentimento daqueles que a submetem; o poder não é puramente jurídico, mas age junto com o direito, buscando uma coincidência entre os objetivos de ambos; o poder sofre um processo de objetivação, que precede as vontades dos governados ou da lei, desaparecendo a característica de poder pessoal; em direção a uma racionalização, desenvolveu-se uma técnica de poder que o torna despersonalizado (poder do grupo, poder do sistema) e busca formas mais sutis de atuação, sendo a coação reservado o caráter de força extrema. (CHALITA, 1998, p. 13-14).

O poder, é claro, não subjaz somente nisto. O que buscamos evidenciar é a relação entre subordinação e subordinados, em que a psique humana está apegada aos anseios pelo domínio de espaço, da constituição de seus territórios de usufruição. Nunca a luta pelo espaço foi tão ardilosa e necessária, dada a rarefação dos lugares onde ainda se pretenda legislar a sociabilidade e a civilidade dos indivíduos.

O projeto urbano-metropolitano contemporâneo tem no seu bojo as mesmas expectativas que a cidade renascentista e moderna tinha: a liberdade e a igualdade entre os homens, o desenvolvimento pleno, um autêntico projeto de racionalização da humanidade, rumo à perfeição.

Mas o projeto mostra sinais visíveis de fracasso, e a era "pós-moderna" tenta escamoteá-los através da legitimação da técnica e da ciência. Na medida do possível, tentase corrigir as conseqüências das disparidades sociais, procurando não afetar demasiadamente o status quo. Esse é o novo discurso, propalado em massa pela mídia, pelo sistema político e por diversos setores acadêmicos. Assim sendo, a metrópole tornou-se o lócus privilegiado da territorialização desses discursos e práticas "pós-modernos".

O ordenamento territorial como já vimos, não está em voga pela simples questão da "revitalização e do embelezamento dos espaços urbanos debilitados": sua ação, de cunho político e vinculado ao status quo, está ligado à adequação da estrutura espacial preexistente que, na eclosão de novas territorialidades e contra-poderes a todo instante surgindo e programando o solapamento do atual sistema hegemônico, o planejamento 


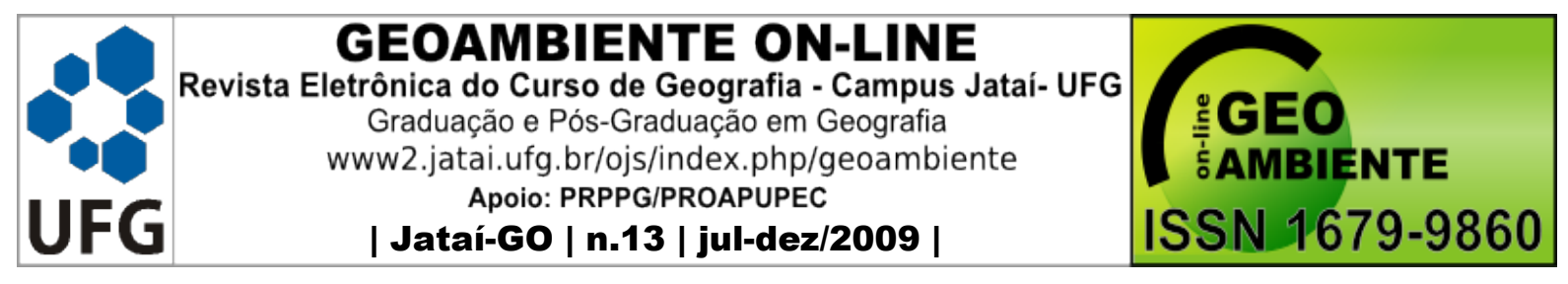

territorial e a ação posterior aparecem e tornam-se salutares para a reconfiguração da base espacial, já que, por ela ser na sua essência uma forma-conteúdo fragmentada, articulada, reflexo e condicionante social, estaria fadado a alastrar as disparidades sociais, causadas pelos novos padrões de reprodução da sociedade capitalista, onde este espaço estava inadequado aos novos modelos de existência e reprodução das hegemonias sociais. Essa contradição, lançada em germe pela ordem elitista, é algo que ela reconhece como sendo da sua autoria, e por isso, a sua busca incessante por novas soluções que lhes darão a rota de fuga, frente aos embaraços produzidos pela nova (des) ordem socioespacial.

Por isso, quando pode, está trabalhando para se reaparelhar, mudando os seus próprios instrumentos e meios para impor o consenso societário e coagir quando os meios pacíficos não funcionam. Enfim, a busca do ordenamento territorial é a busca pela racionalização societária, de novas formas de reprodução das hegemonias sociais e dos espaços liminares.

Passado a fase fin-de-siècle, com o discurso do fim das utopias e a constatação de novas práticas, calcadas nos ideais pós-modernos, como a exaltação ao individualismo e o consumo desenfreado das imagens e produtos como a essência dessa nova vida forjada por esses ideólogos pós-estruturalistas, a sociedade urbana deu com os "burros n’água”, pois, pelo que até agora observamos, essas novas práticas não estabeleceram uma paz social, uma forma de convivência pacífica dos diferentes grupos, dado as diferenças gritantes que há entre eles. Com um olhar atento sobre a formação socioespacial das metrópoles contemporâneas (principalmente as metrópoles dos países periféricos e semiperiféricos), constatamos que a maioria desses grupos vive nos estilhaços desse novo espaço-tempo forjado e construído pela técnica e pela ciência moderna, e não possuem anseios, expectativas, rumos a tomar, e o pior: estão alienados não apenas nas relações de trabalho, mas também, no seu próprio espaço vivido.

Formatou-se um choque de padrões entre a psique e a sociedade e o homem urbano agora encontrou uma nova razão de viver, razão esta que é programada e dirigida pelos meios de comunicação e produtos que fetichizam e ditam os predicados da vida urbana. 


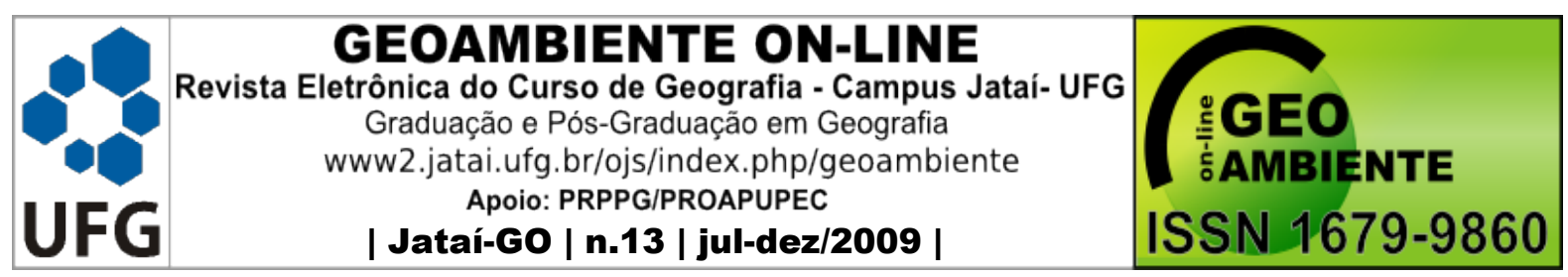

A cidade, agora, é o lócus não mais do habitar, do encontro entre diferentes, mas sim da exibição, da luxúria e do consumo visual das paisagens criada pelo urbanismo décor. Um novo mobiliário urbano tenta incutir no indivíduo a sensação de ambiência plena, uma satisfação por ser cidadão e "participar" do ritmo da cidade.

A idiossincrasia é anestesiada, todos os indivíduos agora pensam as mesmas coisas, reagem de maneira idêntica aos acontecimentos transmitidos pelos meios de comunicação de massa, possuem os mesmos gostos e vontades, logram pela ascensão social e são indiferentes para com o próximo, a não ser que esse próximo seja um pistolão, paraninfo, patrão, padrinho, etc, vital para que sua carreira profissional e "social" de uma guinada"

As conseqüências desse novo ritmo social são: o consumo desenfreado e na maioria das vezes, desnecessário dos produtos; o gosto das pessoas coordenado pela mídia, o individualismo, o privatismo, a luxúria, os painéis publicitários, a infestação multicolor dos bancos, o estetismo "sem forma" dos novos edifícios pós-modernos, a paisagem históricocultural transformada apenas em um playground para diversão dos citadinos nos finais de semana, etc.

Barbosa rebate a questão com o seguinte argumento:

A reificação das relações sociopolíticas se reproduz nas cidades como expressão do fetichismo de um mundo convertido em imagens espetaculares. Imagens que se banalizam e logo se degeneram no ato de sua difusão massificante, para serem substituídas com o mesmo teor generalizante da ilusão de um presente perpétuo, apesar de efêmero. (BARBOSA, 2006, p.131).

A respeito da superficialidade das novas relações de reprodução da sociedade urbana, continuamos com Barbosa:

Sob a égide de uma identidade abstrata e efêmera edificada pela cultura narcísica, o ato de viver na cidade torna-se cada vez mais mecânico e programado, promovendo um processo inaudito de reificação das relações sociais. Estas conformam a profunda crise da esfera pública, cujo significado mais explícito pode ser observado no desapego e na ausência de compromisso com a vida social e no enfraquecimento dos atos e

${ }^{11}$ Uma abordagem mais "sociológica" sobre as áreas de passagem e as práticas individualistas e/ou interesseiras do indivíduo moderno (e do indivíduo brasileiro, principalmente) são vistas em DA MATTA, Roberto. Carnavais, malandros e heróis: para uma sociologia do dilema brasileiro. 6. ed. Rio de Janeiro: Rocco, 1997, p.181-248. 


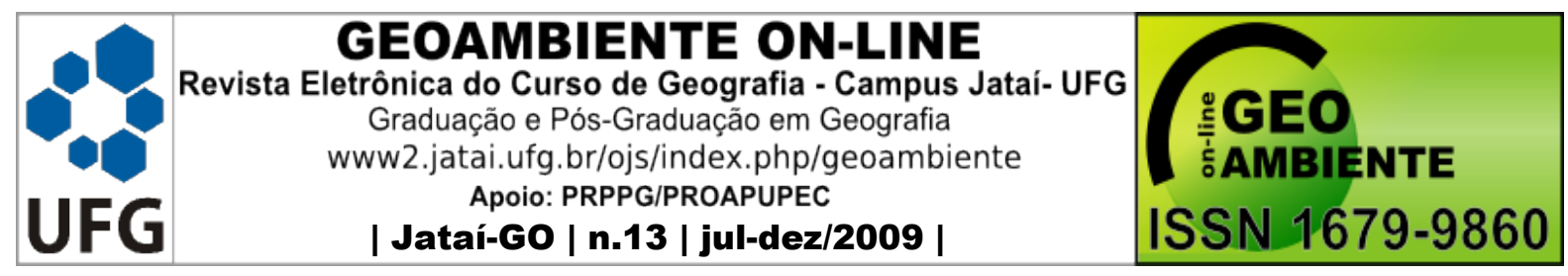

comportamentos de caráter mais coletivo no espaço urbano. (BARBOSA, 2006, p. 137).

Se a sociedade está, de fato, perdendo seus valores de cidadania, crescendo a "incivilidade" e a alienação desembestada fomentada pelos meios de comunicação, por outro lado, a aparente ordem estabelecida está afunilada pelos antagonismos sociais, criando-se verdadeiros "hematomas" no espaço (milícias, traficantes, grupos étnicoracistas, gangues de rua, etc) e os detentores do poder vêem-se constantemente ameaçados por esses contra-poderes, em outras palavras, por esses contra-espaços que são criados pela própria lógica de reprodução do sistema urbano-capitalista: a reprodução das hegemonias sociais e dos espaços liminares.

O contra-espaço é o modo espacial por meio do qual excluídos e dominados põem em questão a ordem espacial instituída como forma de organização da sociedade, rejeitando ou copiando o modo de vida que ela impõe aos que vivem embaixo e dentro dela. Pode ser contra-espaço um movimento de confronto, de resistência, de mimetismo ou de simples questionamento da ordem espacial existente. (MOREIRA, 2006, p. 101).

Em uma abordagem foucaultiana, para que aja continuidade das relações de poder pelos atores hegemônicos, estes precisam reaver persistentemente os seus dispositivos de segurança. O espaço seria então, testemunho e veículo das "micropolíticas" do poder, alicerçando e articulando a sociedade em geral ao poder estatal, o "centralizador" da ordem disciplinar.

O panoptismo, noção foucaultiana que destaca a "invenção tecnológica na ordem do poder" (FOUCAULT, 2007, p. 160), se justifica na construção de estruturas arquitetônicas e espaciais para instrumentalizar e corroborar o exercício do poder.

$\mathrm{Na}$ metrópole do Rio de Janeiro, esse poder onisciente e onipresente (este multifacetado), disciplinarizador dos corpos, que distribui os indivíduos no espaço, aciona os dispositivos disciplinares assim que o "caos" se apresenta, está a se chocar com o contraespaço das gangues de rua, do tráfico de drogas e caça-níqueis, das milícias (formados por polícias, bombeiros, soldados) que tomam as favelas, dos grupos identitários e racistas, do circuito informal da economia, das torcidas organizadas que vêem nos jogos um momento 


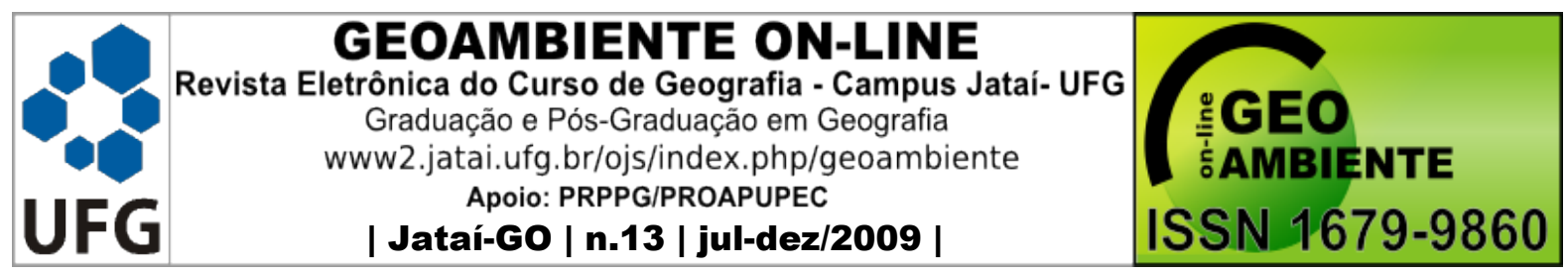

para profanar todas as seqüelas que são criadas por essa vida urbana hostil, a ponto de usar da violência (a expressão máxima do vigor natural que está entranhado nesses indivíduos durante toda a semana) como forma de poder "soltar o bicho". O território é condição "estratégica" de reprodução das torcidas e de outras tribos/gangues. A compartimentação e exclusividade dos espaços por estes grupos vêm a decretar, de forma ardilosa, a conquista e manutenção desses grupos ao longo da malha e bifurcações urbanas.

Tal questão é posta por Gomes:

A superposição dos diversos "mapas" oriundos desses movimentos nos dá uma imagem muito diversa daquela, apresentada classicamente, da pacificada cidade democrática. Tribos em luta, territórios sob disputa, trajetos proibidos, barreiras levantadas, mensagens cifradas, as grandes metrópoles são o palco de muitas guerras, objeto de variadas territorialidades. Dentro dessa perspectiva, é o próprio sentido de cidade que está em jogo. (GOMES, 2002, p. 251).

E é neste palco de conflitualidades que o nomoespaço ${ }^{12}$ é justificado, tendo como efeito, a racionalização societária, despindo-a de sentido e empobrecendo o espaço vivido. Essa perda de sentido condiciona a uma racionalização cultural. $\mathrm{O}$ que fazer então diante dessa permanente e "temível" dialética?

Traçando o perfil de uma metrópole como a do Rio de Janeiro, que possui um contexto sócio-histórico-cultural totalmente diverso das outras metrópoles que experimentaram um desenvolvimento cadenciado, de longo prazo e, na medida do possível, correto, apesar das vicissitudes inerentes a uma sociedade que possui diversos contextos dentro da sua dinâmica, o desenvolvimento socioespacial que ele deve adotar não é pertinente com os planejamentos e gestões praticados pelos países europeus, por exemplo. Esses projetos importados, ao serem postos em prática, mostram-se insensíveis para com o espaço herdado, as técnicas novas não possuem nenhum vínculo com o patrimônio

\footnotetext{
${ }^{12}$ Devemos, contudo, ressaltar os possíveis perigos que este conceito pode acarretar, gerando análises e conclusões "biologizantes", "reificantes" e "essencialistas" do território e das relações sociais cotidianas. Para aprofundamento desses dois modelos de apreensão das relações sociais num dado território, o nomoespaço e o genoespaço, ver GOMES, P. C. da C. A condição Urbana. Rio de Janeiro, Bertrand Brasil, 2002.
} 


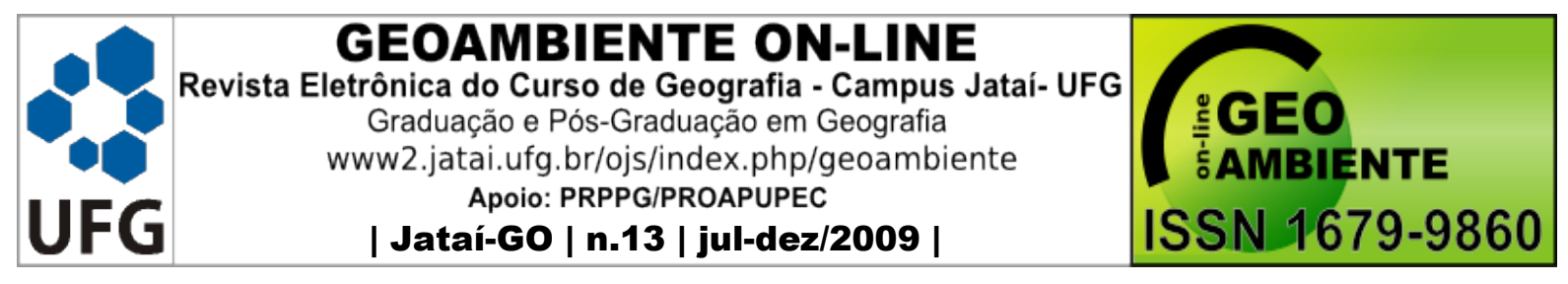

histórico-cultural, terminando por criar um espaço-tempo de novas formas e estruturas espaciais indiferentes com o passado.

A cirurgia urbana realizada no Rio de Janeiro no início do séc. XX sob os auspícios do então engenheiro e prefeito Pereira Passos (que levou o nome do projeto: A Reforma Passos), é um exemplo emblemático de como as ações políticas que não levam em conta o contexto histórico levam o espaço a uma "fornicação" que acaba por descaracterizar parte da sua história.

A remoção dos cortiços e dos pobres, levando à formação e ampliação do número de favelas; as políticas públicas desigualmente travadas no subúrbio carioca - criando a famosa dicotomia Zona Sul, Barra da Tijuca e Recreio para os ricos; Zona Norte, Oeste e Baixada para os pobres -, entre outros fatores não menos relevantes, é um convite para repensarmos seriamente sobre qual tipo de sociedade lutamos. Se o modelo civilizatório está em crise faz tempo, há a possibilidade de programarmos novos modelos de sociedade/comunidade? Se sim, como nos desligarmos do atual modelo que impregna as mentes e atitudes dos políticos, tecnocratas, intelectuais e do público em geral? É o momento de trazermos à tona teorias consideradas revolucionárias como o marxismo, o trotskismo, ou, pensar em modelos que não tratem o ser humano como mônadas isoladas, como indivíduos que cumprem papéis estáticos e definidos dentro do sistema, ignorando as interações e relações ${ }^{13}$ ?

\section{6 - Considerações finais}

Romper o vício pelo "moderno" (ou seria melhor dizer "euro-americanismo"?), pelo exterior inovador-capitalista, é um fator crucial. Romper com a lógica ditada pelos "de fora" é afirmar que o desenvolvimento socioespacial na metrópole não se basta apenas pelo aumento das áreas urbanizadas e/ou pela concomitante "ocidentalização": esses espaços, que são territorializados por distintos grupos e pelos quais possuem suas próprias

\footnotetext{
${ }^{13}$ Reflexão tirada de VELHO, Gilberto. O observador participante (Apresentação à edição brasileira). In: WHYTE, William Foote. Sociedade de Esquina: a estrutura social de uma área urbana pobre e degradada. Rio de Janeiro: Jorge Zahar Ed., 2005.
} 


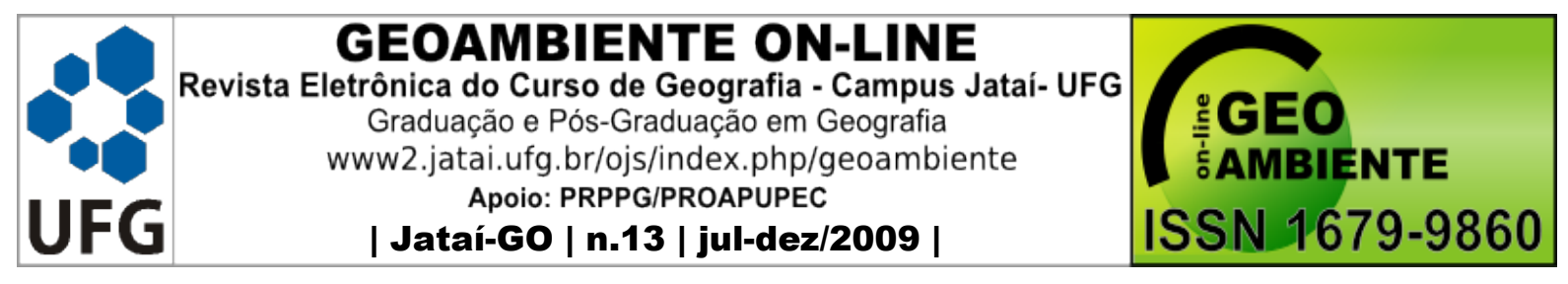

representações espaciais, precisam ser olhados e tratados como territórios que aspiram à autonomia, ao desenvolvimento e gestão plenos.

Em se tratando principalmente de grupos subalternos, dos alijados pelos processos capitalistas, o debate sobre o desenvolvimento não pode estar desvinculado da visão de mundo, do padrão de vida e dos projetos desses indivíduos e grupos, tomados como agentes que criam uma ação coletiva, que atuam juntas visando um objetivo comum.

A actio popularis é a chave para a autonomia dos territórios. Mas para tal fim, é preciso gerar mecanismos que tragam efetiva representatividade à sociedade civil, abandonando a condição de "ator passivo" dentro do jogo de decisões e ações tomadas pela elite e pela burocracia (FERREIRA, 1983, p. 25). onde os indivíduos tenham autonomia para questionar e combater o discurso equivocado e descontextualizado que ronda o seu cotidiano; que possam fugir do "óbvio" e caminhar pelos pastos verdejantes do diálogo e da prática, que inclui o respeito para com as diferenças do outro e a preocupação permanente com as questões que estão no bojo dos processos que se expressam no espaço.

Que o atual sistema em vigor possa ser questionado por esses espaços-território autônomos, pensando em alternativas de desenvolvimento socioespacial sustentáveis, que subvertam a estrutura capitalista e seu lema Abusus non tollit usum ${ }^{14}$.

A luta contra a subordinação dos lugares pelo sistema capitalista começa, e aqui repito mais uma vez, pela autonomia dos territórios, em prol do pleno desenvolvimento e fortalecimento dessas localidades, onde elas possam tornar-se auto-suficientes na sua formação socioeconômica; que aja o resgate/reafirmação das especificidades sociohistórico-culturais, não se esquecendo de sermos "universalistas" ao mesmo tempo, exercitando a alteridade, lutando por uma sociedade mais igualitária.

Para finalizarmos, sugiro as sábias palavras de Milton Santos (2005, p. 92): “O que importa agora é preservar o papel das cidades locais, sem todavia consagrar e conservar disparidades, e integrar essas cidades em um mecanismo de crescimento que seja geral e não seletivo".

\footnotetext{
${ }^{14} \mathrm{O}$ fato de ter ocorrido abuso não deve prejudicar o uso.
} 


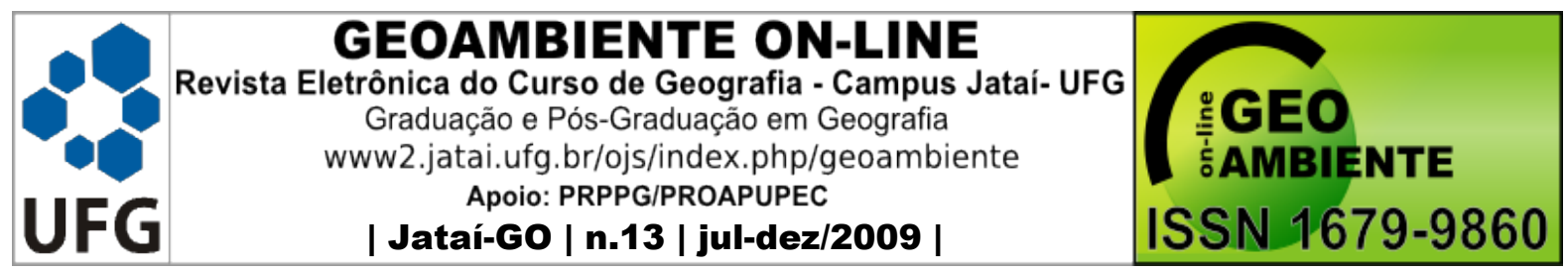

\section{7 - Referências Bibliográficas}

BARBOSA, J. L. O ordenamento territorial na era da acumulação globalizada. In: SANTOS, M. et al. Território, territórios: ensaios sobre o ordenamento territorial. Rio de Janeiro: DP\&A, 2006. p. 125-145.

BECKER, B. A geopolítica na virada do milênio: logística e desenvolvimento. In: CASTRO, I. E., GOMES, P. C. C., CORRÊA, R. L. (orgs.). Geografia: Conceitos e temas. Rio de Janeiro: Bertrand Brasil, 1995. p. 271-307.

BERNARDES, J. A. Mudança técnica e espaço: uma proposta de investigação. In: CASTRO, I. E., GOMES, P. C. C., CORRÊA, R. L. (orgs.). Geografia: Conceitos e temas. Rio de Janeiro: Bertrand Brasil, 1995. p. 239-269.

CHALITA, G. B. I. O poder. São Paulo: Saraiva, 1998.

DALLARI, D. A. Teoria Geral do Estado. São Paulo: Saraiva, 1995.

DA MATTA, R. Carnavais, malandros e heróis: para uma sociologia do dilema brasileiro. Rio de Janeiro: Rocco, 1997.

FERREIRA, F. W. Planejamento sim e não: um modo de agir num mundo em permanente mudança. Rio de Janeiro: Paz e Terra, 1983.

FOUCAULT, M. Microfísica do Poder. Rio de Janeiro: Edições Graal, 2007.

GOMES, P. C. C. A condição Urbana. Rio de Janeiro, Bertrand Brasil, 2002.

HAESBAERT, R. Territórios alternativos. São Paulo: Contexto, 2006a.

. Concepções de território para entender a desterritorialização. In: SANTOS, M. et al.

Território, territórios: ensaios sobre o ordenamento territorial. 2. ed. Rio de Janeiro: DP\&A, 2006b. p. 43-70

. O mito da desterritorialização: do "fim dos territórios" à multiterritorialidade. 2. ed. rev. Rio de Janeiro: Bertrand Brasil, 2006c.

HARVEY, D. Condição pós-moderna. Uma pesquisa sobre as Origens da Mudança Cultural. São Paulo: Loyola, 1992.

MASSEY, D. Pelo espaço: uma nova política da espacialidade. Rio de Janeiro:

Bertrand Brasil, 2008. 


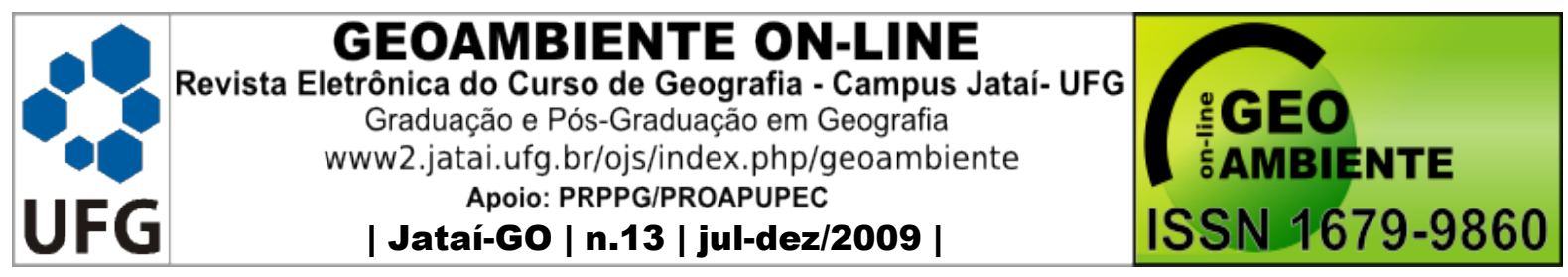

MOREIRA, R. O espaço e o contra-espaço: as dimensões territoriais da sociedade civil e do Estado, do privado e do público. In: SANTOS, Milton. et al. Território, territórios: ensaios sobre o ordenamento territorial. Rio de Janeiro: DP\&A, 2006. p.71-107.

RAFFESTIN, C. Por uma geografia do poder. São Paulo: Ática, 1993.

SANTOS, M., SILVEIRA, M. L. O Brasil: território e sociedade no início do século XXI. Rio de Janeiro: Record, 2005.

SANTOS, M. A Natureza do Espaço: Técnica e Tempo, Razão e Emoção. São Paulo: EDUSP, 2006.

. Da Totalidade ao Lugar. São Paulo: EDUSP, 2005.

SILVA, L. R. A natureza contraditória do espaço geográfico. São Paulo: Contexto, 2001.

SOUZA, M. J. L. O Desafio Metropolitano. Um Estudo sobre a Problemática Sócioespacial nas Metrópoles Brasileiras. Rio de Janeiro: Bertrand Brasil, 2000.

. O território: sobre espaço e poder, autonomia e desenvolvimento. In: CASTRO, I. E., GOMES, P. C. C., CORRÊA, R. L. (orgs.). Geografia: Conceitos e temas. Rio de Janeiro: Bertrand Brasil, 1995. p. 77-116.

WHYTE, W. F. Sociedade de Esquina: a estrutura social de uma área urbana pobre e degradada. Rio de Janeiro: Jorge Zahar Ed., 2005. 